\title{
College and University Archives: Three Decades of Development
}

\begin{abstract}
This article considers the role of college and university archives from the perspective of their research function. The research role is seen as emerging somewhat erratically from a background of confusion and misconceptions regarding archives and their contents. When archives have a stated purpose and administrative support and when they are properly organized under direction from trained personnel, their research role can expand. The results have implications beyond the institution and reflect the larger society outside its walls.
\end{abstract}

$\mathbf{T}$ HE SOCIETY OF AMERICAN ARCHIVISTS defines archives as "the noncurrent records of an organization or institution preserved because of their continuing value."1 These records represent the activity of the institution; they are created with a purpose in a certain orderly fashion. "An archive is the shadow of an organization and owes its being to it." 2 In college and university archives, one would thus expect to find administrative records of various kinds: student, faculty, and departmental records, records of campus societies and clubs, etc. The activity of a college or a university, however, is not only reflected in the official records but also in material generated by individuals in their interaction with and work for the institution: the president's correspondence, research manuscripts and lecture notes of faculty, student notebooks and reports, campus publications, and memorabilia. It is in the combination of these two broad types of material that many institutions today see the true college and university archives. ${ }^{3}$

In some institutions, space and staffing problems prevent the two parts from being housed together. In others, the archives also contain regional history collections or special collections, which tend to obscure

Annabel Straus is librarian, Cathedral Chapel School, Los Angeles, California. the direct relationship that the institution should have with its archive. Special and regional history collections are outside the scope of this paper. It must also be noted that, although this paper addresses itself to institutions with archives of some sort, the figures cited further on clearly point to the large number of institutions that lack archival programs altogether.

Most authors who write in this field agree that the main reason for the existence of college and university archives is to provide opportunities for research. However, the archival movement on behalf of institutions of higher education in this country began less than three decades ago and is still considered to be in the developmental stage. Consequently, much of the literature is concerned with the practical aspects of archives: how to establish archives, how to get administrative and financial support, and how to manage and staff them. These concerns tend to overshadow, if not completely to obliterate, the research role. Although this role has been kept alive in scattered institutions from the beginning of higher education, the role has been a very limited one.

In recent decades, two factors have indirectly had a revitalizing effect on that role and even made it possible to expand on it. One factor has been the defining and dissemination of archival theory with its emphasis on provenance and original order of materials. ${ }^{4}$ The other has been the introduc- 
tion of records management with its planned schedules of disposal, retention, and destruction of records. ${ }^{5}$ Together, archival practice and records management have brought about a thorough housecleaning in archives and a need to rethink the purpose for archives.

In the case of college and university archives, the Society of American Archivists Committee on College and University Archives (hereafter referred to as the SAA Committee), individual institutions, the archivists themselves, and even the researchers, have contributed to their development. What has begun to emerge from the literature in regard to research is that the properly organized and efficiently run archive can be a source of much more than the institutional history or the biography of the founder.

As college and university archives have been changing and developing, so have its keepers. In the past, the keeper was usually a librarian with many other duties, or a history buff faculty member, or a combination of the two. In any case, these individuals were in general able to give only sporadic or part-time attention to the archives. The archive was located in the library building and part of the library organization. Today's college and university archives are still more often than not associated with the library both physically and organizationally, but the keeper is now an archivist with different training and separate duties from those of the librarian. In some institutions the university archivist has faculty status and is a member of the committee on university archives. ${ }^{6}$

\section{SURVEYS OF THE FIELD}

In order to acquire a perspective on the development suggested in the title of this paper, it is helpful to consider what college and university archives were like when the SAA decided to look into the matter. The Committee on College and University Archives was established in 1949. It was felt that college archivists needed to establish a working relationship in view of the increased interest in records on the part of their institutions. The committee set to work in five areas:

1. The establishment of standards for the proper handling and care of college and university archives.

2. Securing the appointment of competent archivists in colleges.

3. Establishing a clearing house for the peculiar problems of such archivists.

4. Developing in administrators a greater consciousness of archives as an integral part of college and university administration.

5. Discovering the nature and extent of all college and university archives now extant, as a basis for future study. ${ }^{7}$

Clearly, the field of college and university archives was considered to be very much in its infancy. This was confirmed by the first survey the committee conducted. The survey covered 150 randomly selected institutions of which 115 answered. Only 56 institutions reported that they had archives and an archival program. ${ }^{8}$

The survey also revealed confused notions as to what constitutes a college or university archive. Reporting on the survey, Dwight H. Wilson, chairman of the committee, wrote:

One university archivist, for example, stated that his work of collecting business records was of more importance than collecting and preserving the official records of his university! Yet Federal and State archivists have been preaching for years that it is the business of an archival agency first to serve the institution or organization that created it. Another school announced the establishment of its archives department with the avowed purpose of collecting the records of the city in which the college is located. . . .

Too many of the schools reporting apparently have not yet comprehended the modern objectives of archival agencies. ${ }^{9}$

Even when an archive existed at an institution, it tended to be hidden away and little known.

The head of a department at one of the larger universities questioned me at length about the raison dêtre of archives, and ended the conversation with: "Well, I am very interested because we don't have any such program at the University of. ..." The very next week I learned that his school had had an archivist for the past 6 years! ${ }^{10}$

The bleakest picture of college and university archives was presented in the 1960 s by a writer who described their prevalent state as "a kind of American way of archival death." 
In fact, what is most often denominated the archives of many universities and colleges usually consists of a collection of unrelated historical manuscripts that may or may not have any basic unity or any reason for preservation other than relative antiquity. As an afterthought, there may or may not also be included in the "university archives" a hodgepodge of institutional exotica such as class banners, club totems, banquet menus, and the like. Doubtlessly-and hopefully-the apex of such archival nonsense was reached several years ago in one university in the East. For some time, according to the archivist who ultimately brought order, system, and meaning to the institution, the archives of that university was the repository for the ashes of one of the university's founders. ${ }^{11}$

Such burial chambers demonstrate what the result is when there are no stated purpose and no administrative support for the archives, and no qualified or even interested personnel to care for them.

In contrast, another article presents a more positive picture of an institution where a group of students long ago formed a "memorabilia society," which had as its purpose "the collection of college publications, programs of college entertainments, newspaper accounts of college affairs and items concerning students, photographs of members of the graduating classes, and all other memorabilia" as they related to the college and its history. ${ }^{12}$ With this modest plan, support, energetic work, and luck in finding interested keepers along the way, this "memorabilia" collection survived and grew. Today it is a functioning archive with its own archivist.

\section{The Collegiana Collection}

Ever since the beginning of higher education in America, many institutions have been and continue to be interested in preserving material that documents the history and development of the institution through the papers of founders, presidents, faculty, alumni, and descriptions of student life and curricula.

Representative examples of this type of archives are described in a thesis by M. R. Powers in 1952. ${ }^{13}$ Powers surveyed the "collegiana collections" at four colleges in Pennsylvania, three private and one public, with enrollments of $500,850,11,500$, and 17,500 students, respectively. All were founded around the middle of the nineteenth century. The collegiana collections of each were housed in the library. The two larger institutions provided separate rooms for the major part of their collections that were in charge of curators, but the two smaller ones had no separate rooms nor was any staff member assigned full time to care for the collections.

The materials in these collections were a mixture of the truly archival, for example, early financial records, minutes of faculty meetings and of the board of trustees, and other material that included "files of old letters, .... documents concerning the founding of the College, and presidential papers, also diaries, scrapbooks, notebooks." 14 Official college publications were featured, as were those of faculty and alumni. In addition, there were pictures of trustees and faculty, presidential portraits, and photographs of buildings and events. A typical memorabilia collection consisted of "candlesticks used in the 1860s, an old handbell, pins, canes, a peace pipe, and the College seals." 15 Because of lack of space and for reasons of security and preservation, old manuscripts, the files of early records, and other material deemed particularly valuable from a historical point of view, were housed in a vault in the library basement.

Archival arrangement is not mentioned in the survey, but one of the small colleges did keep its noncurrent official records separated by categories, a feature of archival practice. At the other three institutions, more recent noncurrent administrative records were kept at the originating offices or in charge of the registrar's office. Records management is not mentioned.

The services offered at these institutions centered on reference and research. The two curators were, of course, able to offer better and more knowledgeable service to their clientele than was the case at the two smaller colleges.

The principal clientele at the time of this survey consisted of administrative officers, faculty members, publicity departments, and students in search of theme topics or feature stories for campus newspapers. In addition, all four collegiana collections furnish materials for exhibits. ${ }^{16}$

The research use, then, of these collegiana collections-cum-archives was almost 
exclusively internal, not counting requests by mail from distant alumni. The results from research done there generally stayed within the institution. ${ }^{17}$ Nevertheless, possibilities and opportunities for research existed and were explored to some extent, although no published results are specifically mentioned in the text of the thesis. ${ }^{18}$ Certainly, collegiana collections of this type have progressed beyond the early stages of the "memorabilia society," not to speak of the gulf between them and the "archival death" version.

The more substantial results of research using such collegiana collections might take the form of a biography of the founder, a president, or a famous alumnus. But in terms of affecting the very birth-or death-of many college and university archives, the plans for writing an institutional history have been of crucial importance. Sometimes an archive is begun because a professor on sabbatical leave decides to write that history. ${ }^{19}$ Sometimes the published history spells the end of the archival effort. One institution stated that "because a comprehensive history of the institution had been published ... there was no longer any need to retain the records-or have an archives."20

Usually the history of an institution gets written because the college or university is approaching an important anniversary.

a centennial celebration stimulatd the use of the college's historical records and a search for the college's real past. ... The trustees authorized a faculty member to write the institution's history; his research brought home the need for an archive. $^{21}$

Recognizing a need does not necessarily mean that action follows. "Nothing can be done until key faculty and administrators agree that the helter-skelter dispersion of records is fundamentally unsound and that something must be done about it." ${ }^{22}$ Progress can be very slow. One university waited forty-three years before a recommendation to establish an archive was acted on. ${ }^{23}$

Dozens of practical questions will be raised about archival techniques, policies, and procedures, and no one with the proper expertise will be available. Men in the history department know archives only as readers. The college librarian may give general support, but he probably has no training in archive management. ${ }^{24}$

These problems, and variations on them, were encountered by institutions trying to set up archival programs whether for practical or research-oriented reasons.

\section{THE ARCHIVAL SCENE IN THE 1960S}

During the 1960s there was increased activity on the archival front just as there was on the front of the whole educational field. The SAA Committee conducted two surveys in that decade: in 1962 and in $1966 .{ }^{25}$ The 1962 survey added 200 colleges and universities to the 150 surveyed in 1949 . Of these 350 institutions, 268 replied; of these 113 reported they had archives and either a full-time or part-time archivist. Although the number of "haves" was now larger, the percentage was actually smaller. The overall picture was not too bright. To balance the negative aspect, it was pointed out that all of 133 institutions said they were seriously planning archival programs. ${ }^{26}$

The 1966 survey was the first comprehensive one of archives in accredited colleges and universities. It covered 1,156 institutions in the United States and a number in Canada. This time, 558 schools here, or 48.3 percent, claimed to have archives, but only fifty-three, or 9 percent, employed full-time professional archivists.

From the 1966 survey, it is apparent that college and university archives are still in the developmental stage. For most institutions, the management of archives is a side function of the library. Full-time college archivists are rare. Holdings except for two or three dozen large institutions are relatively small. These negative conclusions should not obscure the most important fact that there is general acceptance by higher educational institutions in the United States and Canada of the idea of preserving their archives-a statement which could not have been made two decades ago. ${ }^{27}$

As indicated earlier, it was the introduction of records management techniques that really helped promote the idea of preservation of college and university archives. Since World War II, the growth in enrollment and curricula had increased the accumulation of records to an alarming extent.

Records management provided practical solutions to a very real problem, namely 
that of running an institution in a more efficient and businesslike fashion. ${ }^{28} \mathrm{~A}$ records disposal schedule stipulates that noncurrent records of permanent value are to be placed in the archives. It is not just the enduring administrative value of the records that is taken into consideration, but also the historical value, thus suggesting their future use for research. The real and obvious utility of a records management program served in numerous cases to speed up the establishment of archives, or to justify existing ones. "Several university archives have justified their existence and budgetary allocations by assuming full responsibility for the management, appraisal, preservation, and destruction of institutional operational records." 29

There is today, then, a merging of the older collegiana-type collection with the true archive of noncurrent records. Whether housed together or apart, these double-faceted archives, which have firm administrative support, clearly stated archival programs, and trained archivists in charge are increasingly able to expand their research horizons beyond the student paper, the biography of the founder, and the institutional history. Some college and university archives have, of course, always been aware of that expanding horizon. The archival movement on behalf of these institutions has brought additional archives into being, and, in so doing, it has increased the potential for research too.

\section{ARCHIVES AND RESEARCH}

The literature of the three recent decades yields only a few scattered articles covering the research aspect of college and university archives. There is certainly room for more contributions to the field. A number of authors have expressed wishes in this regard. In his article "Arcana Siwash: The Function and Needs of a College Archives," Thomas Le Duc wrote:

$\ldots$ if the archives are to be a part of the intellectual enterprise of the college, and of society, if they are to serve as more than a resort for sentimental antiquarians, they must prepare to meet the needs of professional scholars. ...

... the function of a college is to communicate ideas .... colleges are faithful mirrors of communities ... they reflect the values, the whole faith of the body that lends support and nourishment. ...

It is not only the local scholars that will be attracted, but serious scholars in all fields of learning from other institutions. They will come in search of materials for the histories of art, science, educational practice, and the historical development of thought. Students of social history will discover the rewarding richness of family letters. Biographers will come in search of information on the college days of their subjects. ${ }^{30}$

Today this writer would probably agree that some of his ideas have come true and that some are in the making.

It is quite a jump in time to an article with concrete examples of how broad the spectrum of research can be at a college or university archive. In 1964 Clifford K. Shipton, archivist of Harvard University, wrote such an article, "College Archives and Academic Research." At Harvard, they had also had to realize "that the way to justify the existence of the Harvard University Archives (and to obtain a good appropriation) was to furnish records management service."31 The archivist acknowledges that there are problems when you try to create a research center out of an archive; yet he finds that "college archives are mines of historical treasure that can be exploited without interfering with the bread-and-butter functions of records management." 32

Shipton examined applications for use covering eighteen months. Not surprisingly, the list of his findings is headed by people doing biographical research, approximately 30 percent. History of education draws an equally large group of researchers. Science accounts for 10 percent, and literature, medicine, philosophy, and religion draw about 5 percent each. Geography, bibliography, and political science are at the bottom of the list, with 2 percent each. The smallest identifiable group is concerned with political history. The bulk of the resources used consisted of collegiana-type materials, but the official records also played a noticeable part. ${ }^{33}$

Now, it is true that Harvard as the cradle of all higher education in this country, and as a longtime leader in the field, is in a class by itself. Very few other colleges or universities can hope to provide the resources and services that the Harvard University Ar- 
chives provides. (The 1966 survey discovered, for instance, that Harvard had 30,000 feet of records, whereas the second largest institution had only 12,000 , and the third $8,000$. $)^{34}$

The quality, size, and prestige of an institution often determine the scope of the archival program (if one exists), and the scope of the research function. As an example, Harvard may serve to point the way to a broader archival research base, a base that can be adapted to reflect the particular capacities of the college or university archive in question.

When the college archivist goes beyond his duty to preserve the history of his own institution, he becomes the custodian of source materials covering the entire spectrum of human knowledge. He is faced with the exciting problem of deciding which materials should be preserved for the use of historians yet unborn, working in fields strange to him and perhaps still uncultivated. It may not be the duty of the college archivist to assume this responsibility toward the future, but it is a lot of fun, and I recommend it. ${ }^{35}$

Picking up where Shipton left off, Edith James Blendon in her 1975 article "University Archives: A Reason for Existence," gives a number of examples of the published results of research conducted at college and university archives. She identifies five broad areas in which university archives can serve as resources: "(1) institutional history, (2) intellectual history, (3) social history, (4) political history, and (5) documentary editing." 36 In each area, the writer mentions two or three publications. In the first category Blendon cites what she calls "traditional, administrative, college histories," one of Dickinson College and one of Yale College. Both are based on research in official records.

As an example of a nontraditional history of an institution, Blendon describes Martin Duberman's Black Mountain. For his research on that college Duberman used both state and college archives in North Carolina and supplemented them with tape-recorded interviews.

In the field of intellectual history, Blendon cites Thomas S. Harding's College Literary Societies: Their Contribution to Higher Education in the United States, 1815-76. For his work Harding studied the records of forty-four college literary societies.

Social historians who have an interest in quantitative analysis have also used university archival records. Blendon notes David F. Allmendinger's Paupers and Scholars: The Transformation of Student Life in Nineteenth-Century New England, 17601860. This writer found his data "in matriculation records, biographical directories, and beneficiary account books." The records there showed the social and economic status of students, how they lived, what they studied, and where they went after college.

According to Blendon, researchers in political history have tended to avoid using university archives because of their seemingly narrow, local bias. Perhaps this was also the reason why this area saw the least use at Harvard. She feels, however, that with resourceful use university archives can help "to illuminate aspects of our national experience." As an example, she cites The Separation of College and State: Columbia, Dartmouth, Harvard, and Yale, 1776-1876 by John Whitehead. He used corporation minutes of the four schools to provide a new perspective on the legal, political, and educational history of the nation.

Since university archives often contain personal papers, diaries, unpublished writings and journals, thus documenting a wide range of campus thinking, historical editing can find sources there. Blendon's example is "What Is the Good of History?" Selected Letters of Carl L. Becker, 1900-1945, by Michael Kammen. This work reveals "much of the rich, wide-ranging mind of a great American historian, much about the student-teacher relationship, and much about the nature of the historical profession." 37

Blendon's article not only underlines the range and variety of research possibilities at college and university archives but also indicates the importance of using official records in conjunction with other material. The records serve as the foundation upon which the rest of the work is constructed.

\section{A WindoW ON AMERICAN SOCIETY}

Having come this far, it is now easier to see the potential for "college archives as a window on American society." This is the 
perspective presented by David B. Potts in his 1977 article. ${ }^{38}$ Elaborating further on several areas already mentioned by previous writers, he asks on behalf of that hardy perennial, the institutional history, for more "broadly conceived" works. In addition, he suggests studies that focus on groups of institutions. Such comparative studies would be a far cry from the history written to celebrate one particular institution's centennial. Potts brings out one additional area of research, namely the study of sports within the frame of American collegiate athletics, and the relationship such studies might have to various social and cultural developments in America.

In his footnotes, Potts lists several works, which presumably were researched at college and university archives. Combining Potts' list of works with Blendon's, one finds that a majority of them were published in the 1970s. This fact indicates both the recency and state of the expanding role of college and university archives. Several questions serve to exemplify what Potts' "window on American society" may disclose in the future:

Why did Americans "get hooked" on higher education? ... Did the colleges themselves play a major role in stimulating the demand for higher education? . . .

To what extent were local institutions viewed as denominational or sectarian agencies? . . .

How much revenue was brought into a town by a local educational enterprise, and how was that revenue distributed?...

At what point did higher education begin to function in substantial measure as a means for upward social and economic mobility? ${ }^{39}$
Expanding the research function of college and university as shown here makes the role of the archivist much more than that of a keeper, a manager, and a preserver of archives. The archivist needs to be both a historian and a researcher, or at least to know and appreciate how these delvers into the past think and work. Yet the archivist must not only look back.

The archivist's art at its highest level of development would, I assume, base both day-to-day decisions and long-range plans on skillful anticipation of the answers various data might yield to as yet unasked questions. Archivists, in this sense, operate at much closer proximity to the future than to the past. They must have much better foresight than those of us who are historians. ${ }^{40}$

Their greatest challenge is to convey to the academic researcher the vast potential for profitable research in university archives, and university archivists are uniquely equipped to perform this task. ${ }^{41}$

Looking back now to the list of tasks the SAA Committee set out to complete almost three decades ago, it is clear from the literature that there has been progress, not only in the practical sphere of the mere existence of archives, but also in the intellectual sphere of the research role of college and university archives. The SAA may still deplore the slow and halting development of these archives; the purist archivist may still shudder at the mixture of materials they contain; nevertheless, today many college and university archives have found their spot on the campus map. And some of them are providing the resources for a variety of "maps" of that larger society that these archives reflect.

\section{REFERENCES}

1. Kenneth W. Duckett, Modern Manuscripts (Nashville, Tenn.: American Association for State and Local History, 1975), p.337.

2. Clifford K. Shipton, "Harvard University Archives: Goal and Function," Harvard Library Bulletin 1:101 (Winter 1947).

3. See, for example, J. Joe Bauxar, "Northern Illinois University Archives," Illinois Libraries 57:230-32 (March 1975); Maynard J. Brichford, "The Illiarch," Illinois Libraries 52:182-204 (Feb. 1970); R. E. Miller, “College and University Archives: The Experience of One Institution," College \& Research Libraries 28:113-19 (March 1967); and Clif- ford K. Shipton, "College Archives and Academic Research," American Archivist 27:395-400 (July 1964).

4. For a thorough discussion of archival theory and practice, see Theodore R. Schellenberg, Modern Archives: Principles and Techniques (Chicago: Univ. of Chicago Pr., 1956).

5. Records management in relation to the administration of college and university archives is discussed in the following articles: Helen L. Chatfield, "Records Management in the Administration of College and University Archives," American Archivist 31:243-45 (July 1968); F. Mood and V. Carstensen, "Univer- 
sity Records and Their Relation to General Administration," College \& Research Libraries 11:337-45 (Oct. 1950); William F. Schmidt and Sarah J. Wilson, "A Practical Approach to University Records Management," American Archivist 31:247-64 (July 1968); and Dwight H. Wilson, "No Ivory Tower: The Administration of a College or University Archives," College \& Research Libraries 13:215-22 (July 1952).

6. On the status of the archivist see Robert M. Warner, "The Status of College and University Archives," American Archivist 31:235-37 (July 1968) and David C. Weber, "The Place of the Professional Specialist in the University Library Staff," College \& Research Libraries 26:383-88 (Sept. 1965).

7. "Report of the Committee on College and University Archives," American Archivist 12:62 (Jan. 1950).

8. Ibid., p.63.

9. Dwight H. Wilson, "Archives in Colleges and Universities: Some Comments on Data Collected by the Society's Committee on College and University Archives," American Archivist 13:343-44 (Oct. 1950).

10. Ibid., p.344.

11. Chester V. Kielman, "The University Archives as an Aid to University Programs," Texas Libraries 29:217 (Fall 1967).

12. Jacqueline Haring, "College Arrangement," Illinois Libraries 57:226 (March 1975).

13. M. R. Powers, “A Survey of the Collegiana Collections in the Libraries of the Pennsylvania State College, Temple University, Swarthmore College, and Haverford College," (M.L.S. thesis, Drexel Institute of Technology, School of Library Science, 1952).

14. Ibid., p.15.

15. Ibid., p.16.

16. Ibid., p.56.

17. For further examples of college and university archives, see A. MacDermot, "University Archives in the Boston Area," American Archivist 23:407-14 (Oct. 1960).

18. A couple of institutional histories are cited in the bibliography, Powers, “A Survey," p.58.

19. P. M. Quinn, "Profile in Purple: The North- western University Archives," Illinois Libraries 57:220-23 (March 1975).

20. Philip P. Mason, "College and University Archives: 1962," American Archivist 26:164 (April 1963).

21. W. Kent Hackmann, "Small College Archives: Problems and Solutions," American Archivist 31:271 (July 1968).

22. Ibid.

23. Brichford, "The Illiarch," p.182-83.

24. Hackmann, "Small College Archives," p. 271-72.

25. There was yet another survey conducted in 1972 covering the United States and Canada. The survey reached 1,400 institutions of which 850 answered. See Nicholas C. Burckel, "Establishing a College Archives: Possibilities and Priorities," College \& Research Libraries 36:391 (Sept. 1975).

26. Mason, "College and University Archives," p. 162.

27. Warner, "The Status of College and University Archives," p.237.

28. William Saffady, "A University Archives and Records Management Program: Some Operational Guidelines," College \& Research Libraries 35:204-10 (May 1974).

29. Ibid., p.204.

30. Thomas Le Duc, "Arcana Siwash: The Function and Needs of a College Archives," American Archives 9:132-33 (April 1946).

31. Shipton, "College Archives and Academic Research,” p.395-96.

32. Ibid., p.396-97.

33. Ibid., p.398-99.

34. Warner, "The Status of College and University Archives," p.237.

35. Shipton, "College Archives and Academic Research," p.400.

36. Edith James Blendon, "University Archives: A Reason for Existence," American Archivist 38:176-77 (April 1975).

37. Ibid. p.177-80.

38. David B. Potts, "College Archives as Window on American Society," American Archivist 40:43-49 (Jan. 1977).

39. Ibid., p.44, 45, 46.

40. Ibid., p.43.

41. Blendon, "University Archives," p.176. 